\title{
Preface to the Special issue on Efficiency in Education, Health and Other Public Services
}

Citation for published version (APA):

De Witte, K., Johnes, G., Johnes, J., \& Agasisti, T. (2020). Preface to the Special issue on Efficiency in Education, Health and Other Public Services: International Transactions in Operational Research. International Transactions in Operational Research, 27(4), 1819-1820. https://doi.org/10.1111/itor.12762

Document status and date:

Published: 01/07/2020

DOI:

10.1111/itor.12762

Document Version:

Publisher's PDF, also known as Version of record

Document license:

Taverne

Please check the document version of this publication:

- A submitted manuscript is the version of the article upon submission and before peer-review. There can be important differences between the submitted version and the official published version of record.

People interested in the research are advised to contact the author for the final version of the publication, or visit the DOI to the publisher's website.

- The final author version and the galley proof are versions of the publication after peer review.

- The final published version features the final layout of the paper including the volume, issue and page numbers.

Link to publication

\footnotetext{
General rights rights.

- You may freely distribute the URL identifying the publication in the public portal. please follow below link for the End User Agreement:

www.umlib.nl/taverne-license

Take down policy

If you believe that this document breaches copyright please contact us at:

repository@maastrichtuniversity.nl

providing details and we will investigate your claim.
}

Copyright and moral rights for the publications made accessible in the public portal are retained by the authors and/or other copyright owners and it is a condition of accessing publications that users recognise and abide by the legal requirements associated with these

- Users may download and print one copy of any publication from the public portal for the purpose of private study or research.

- You may not further distribute the material or use it for any profit-making activity or commercial gain

If the publication is distributed under the terms of Article $25 \mathrm{fa}$ of the Dutch Copyright Act, indicated by the "Taverne" license above, 


\section{WILEY}

\section{Preface to the Special issue on Efficiency in Education, Health and Other Public Services}

The efficiency with which producers, especially producers working in the public sector, perform their activities has long been of central interest to practitioners of Operational Research. Despite the relevance for evidence-informed policies, for many government organizations, the measurement of such efficiency is complicated by the complexity of production. These are typically contexts in which a plethora of inputs are converted into a range of different outputs, where the traditional profit objective and often even market prices are absent.

The evaluation of efficiency in such complex situations flourished following the development of data envelopment analysis more than 40 years ago. As the papers in the present special issue demonstrate, numerous advances in this technique have been made through the interaction of applied analysis and methodological progress. The advances include relaxations on the convexity assumption, modelling the operational environment, mitigating the outlying observations, accounting for the interdependency of inputs and outputs in network organizations, or capturing the panel structure of the data.

One of the areas in which the analysis of efficiency using operational research methods has flourished is that of education. Given the strong positive externalities of schooling, provision is characterized by a strong state sector in which explicit prices are absent. This is therefore an ideal laboratory in which to apply the tools of data envelopment analysis. Five papers in the present issue are focused on this sector. Bostian, Daraio, Grosskopf, Ruocco and Weber consider a network in which scientific research produces publications whose results are then applied, in a second stage, within production contexts in which firms employ the technology (that has been improved by the research) to produce (enhanced) output. Their approach blends together dynamic and network data envelopment analysis. The authors show that a combination of improved technical efficiency and more optimal allocation of investment spending across time could result in substantial gains. The second paper in this special issue to focus on education, authored by Segovia-Gonzalez, Dominguez and Contreras, uses data from the Programme for International Student Assessment (PISA) to evaluate the performance of schools in Spain. The authors find that socio-economic factors are important, but also aspects of management are critical in determining performance. In particular, there is scope for managers in state schools to learn good practices from those working in the private sector. Next, Johnes and Virmani use a meta-frontier approach to assess the efficiency of education systems in four developing countries, using internationally comparable data from the Young Lives study. They find that, while there are systematic differences in output across and within countries, once inputs are taken into account no one country strictly dominates the others in terms of efficiency. The next two papers focus specifically on higher education. Ekiz and Tuncer Şakar investigate the efficiency of MBA programmes. Their data are drawn from the well-known Financial 
Times rankings - themselves interesting in that they are calculated using an arbitrary set of weights. The application of data envelopment analysis methods, allowing for much greater flexibility in the determination of weights, provides a useful check on the robustness of such rankings. In the final paper to consider education issues, Agasisti, Shibanova, Platonova and Lisyutkin use Malmquist indices to assess the impact in Russia of the 5-100 project intended to stimulate the excellence of leading universities.

Another important sphere of activity for many governments concerns the provision of health services. As with education, health is an area where a multiplicity of inputs is used to produce a multiplicity of outputs, and where vectors of weights that might otherwise be provided by market prices are unavailable owing to the innately non-market character of provision. Ferreira, Nunes and Marques confront this issue by examining data from the Portuguese National Health Service, focusing on the issue of how financial payments can be structured in such a way as to incentivize cost efficiencies. A second paper on health, by Haeri, Hosseini-Motlagh, Ghatreh Samani and Rezaei, concerns the evaluation of efficiency in a network model of the supply chain for blood products. This includes a complex process of encouraging individuals to donate blood, and subsequently ensuring that blood of the right type is routed to the right destinations.

Jurisprudence provides a further area of government activity in which evaluations of efficiency are becoming increasingly common. In this area too, central government budgets have been squeezed and so the quest for efficiency has become increasingly intense. In a time series analysis that evaluates the efficiency of the Dutch judiciary system, Blank and van Heezik document a severe decline in productivity over recent decades, although this decline has largely been halted in the second half of the period under examination. They attribute the decline to specific policy changes.

Outside the government sector, application of the tools of data envelopment analysis has been more limited. This is due largely to the fact that market prices - the weights that can be attached to inputs and outputs - are readily available, and efficiency can often be measured by examining a company's profitability. Nevertheless, the banking sector has provided a fruitful area for research. Zhao, Kenjegalieva, Wood and Glass examine the efficiency of banks in China, focusing in particular on spatial aspects. They find considerable evidence of spatial autocorrelation in the level of loans supplied by regional urban commercial banks. The efficiency scores achieved by banks are determined in part by the extent of competition in their locale.

As the contents of this issue amply demonstrate, applied work on efficiency analysis is thriving. As the scope of such studies broadens, so the need for methodological innovation becomes apparent. The papers in this issue make interesting methodological innovations, which can also be applied to other fields.

\author{
Kristof De Witte \\ University of Leuven, Belgium, and Maastricht University, The Netherlands \\ Geraint Johnes \\ Lancaster University, United Kingdom \\ Jill Johnes \\ University of Huddersfield, United Kingdom \\ Tommaso Agasisti \\ Politecnico di Milano, Italy
}

